\title{
Carta inédita de Celso Emilio Ferreiro
}

\author{
Claudio Rodríguez Fer \\ Universidade de Santiago de Compostela \\ Cátedra José Ángel Valente de Poesía e Estética \\ claudio.rodríguez@usc.es
}

O 25 de abril de 1978, no mes no que eu cumprira vintedous anos, Celso Emilio Ferreiro escribiume ao meu enderezo estudantil da zona vella de Santiago de Compostela (Patio de Madres 15, $3^{\circ}$ esquerda) unha carta cun poema remitida dende o seu domicilio de Madrid (Juan Bravo 53, 4 , Madrid 6). Na súa misiva comezaba por agradecer e comentar xenerosamente un poema meu, escrito nunha época xuvenil na que eu non tiña intención de publicar poesía para sentirme máis libre e independente dos mundiños literarios, intención que foron minando opinións como a súa:

Querido amigo:

Gracias polo poema, $\tan$ sinxelo e a vez tan fermoso no seu feitío de colaxe perfectamente resolto. Grazas polas súas amáveis palabras.

Coido que anque non queira pubricar debera seguir escribindo poesía. É un grande exercicio prá escritura en prosa e pra o esprito. É tamén un xeito de catarse ou purga dos malos e bós humores.

Logo respondía a un meu pedido de colaboración para un proxecto en marcha:

Respeito a páxina da $\mathrm{Voz}$, sinto non poderlle mandar neste momento mais que ese pequeno poema, que está prácticamente inédito. Esta tempada ando moi escaso de tempo. Mais adiante -se ten a amabilidade de lembrarmomandareille un artigo.

Cos meus saúdos máis cordiais

Celso Emilio Ferreiro

Tratábase do fermoso poema "Homenaxe ao libro", que eu exhumaría posteriormente nun artigo, co título de "Poema inédito de Celso Emilio Ferreiro adicado ao libro", publicado no Diario de Galicia, en Vigo, o 23 de abril de 1988, con motivo da conmemoración do Día do Libro.

$\mathrm{Eu}$ coñecera persoalmente, sendo moi novo, a Celso Emilio Ferreiro en Lugo, concretamente nun abarrotado recital poético no Círculo de las Artes, tras o que logo asistín a un amplo faladoiro con el no barrio de Recatelo. Neste encontro participaron Xesús Alonso Montero e Uxío Novoneyra, así como varios profesores e estudantes entón residentes en Lugo. (Por certo, lembro como anécdota moi íntima que, no Salón Rexio do Círculo, fora a miña nai, asistente ao acto na primeira fila de asentos, quen quedara coas pertenzas de Celso Emilio no colo mentres el recitaba).

HOMENAXE AO LIBRO

Tempo do meu solpor,

Ionxe antano, hoxe perto.

Sobre a paisaxe, abril

é un libro aberto.

Dóe arreo a canseira

do camiñar incerto.

Unha terra, unha frol

é un libro aberto.

Un canto de vendjma

está no outono ixerto.

Cruza o ceo unha pomba

é un libro aberto.

Sóan Yoces no bosque

de brétemas cuberto.

A sobriza devesa

é un libro aberto.

Un aire de cen rosas desgraña o seu concerto.

Un río de palabras

é un Iibro aberto.

Un erbre, que non dome,

un corazón desperto.

A pálpebra incansável

é un libro aberto.

Da libertade falo

é un libro aberto.

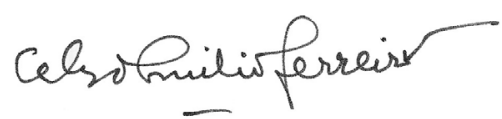


A miña boa química con Celso Emilio prolongouse, tras a morte do poeta, a través da miña relación coa súa muller, María Luísa Moraima Loredo, que sempre foi moi xenerosa comigo. Con ela estiven por derradeira vez cando fun presentar a José Ángel Valente ao Club Faro de Vigo o 24 de abril de 1995, acto ao que Moraima asistiu entusiasmada, pois o seu marido e Valente coñecéranse persoalmente no Congreso 40 anni di poesia in Spagna, celebrado en Venecia no mes de outubro de 1976.

Celso Emilio Ferreiro destinou o poema “Quero ir a Lugo" á homenaxe lucense a Álvaro
Cunqueiro de 1961, evento ao que non asistiu en persoa; logo, en 1962, recolleu tal composición no libro Longa noite de pedra. Reciprocamente, en 1989, "Quero ir a Lugo" foi á súa vez obxecto de homenaxe lucense no opúsculo Celso Emilio Ferreiro desde Lugo, elaborado por sete alumnas miñas do Instituto Ánxel Fole, centro onde eu exercía por entón. Pois ben, máis de medio século despois da creación do poema, Lugo segue agardando por Celso Emilio Ferreiro, coas murallas abertas, substanciado na súa poesía de longa alba de aire, á que aquí se ofrenda esta carta inédita tan chea de humanidade como ela.

Nadrid 25-4-78

Claudio Rodriguez

Compostela

Querido amigo:

Gracias polo poema, tan sixelo e a vez tan fermoso no seu feitio de colaxe perfectamente resolto. Gracias polas súes améveis palcbras.

Coido que ancue non queira pubricar debera seguir escribindo poesía. É un grende exercicio prá escritura en prosa e pra - esprito. L temén un xeito de catersis ou purga dos malos e bós humores.

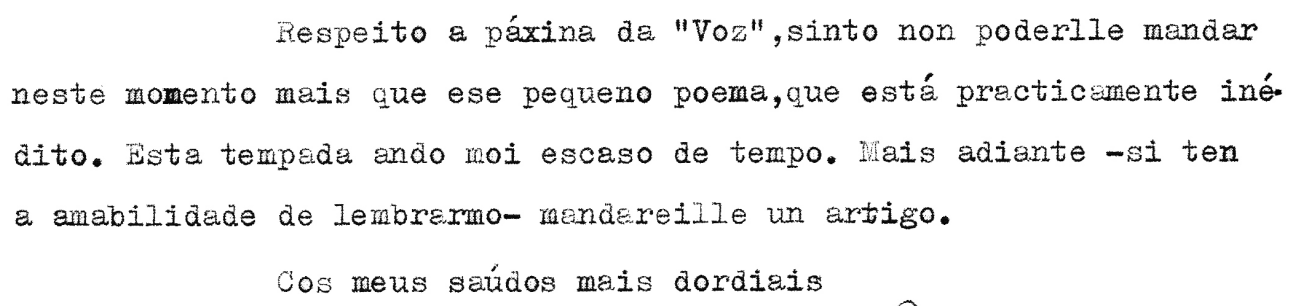

